\title{
フェーズフィールド法による \\ デンドライト凝固シミュレーションの最近の発展 \\ Recent developments of dendritic solidification simulations by phase-field method
}

高木 知弘 Tomohiro TAKAKI

\section{1. はじめに}

合金の凝固過程においては，何がしかのきっかけで液相内 に固相が核生成し，固液界面が液相側に移動することで凝固 が進行する。この際，固相は球状には成長せず，複雑で異方 性の強い樹枝状の形態を呈する。この樹枝状結晶をデンドラ イト (dendrite) と呼ぶ ${ }^{1), 2)}$ 。デンドライトは, 固液界面物性 の異方性と, 固液界面移動時に界面から放出される潜熱の液 相側への拡散，および固相内に固溶できない溶質の液相側へ の拡散などの相互作用によって形成される。このため, デン ドライト成長を数值的に表現するためには，これらの現象を 考慮しつつ固液界面の移動を表現する自由境界問題を解く必 要がある。自由境界問題は, 界面形態が円や球のような簡単 な形状であれば容易に解くことができるが，デンドライトの ように複雑な形態では解くことが困難となる。

フェーズフィールド法 (phase-field method) ${ }^{3) \sim 6)}$ は, 自由 境界問題を界面を追跡することなく比較的容易に解くことの できる手法である。この手法の考え方は, 拡散界面モデルと して Cahn-Hilliard モデル ${ }^{7)}$ やAllen-Cahnモデル ${ }^{8)}$ として知 られていたが，1990年頃に小林がフェーズフィールド法を 用いてデンドライト成長の再現に成功 ${ }^{9), 10)}$ したことが引き 金となり，フェーズフィールド法という名称で統一されて いった。現在では, 定量モデルの発展によって, フェーズ フィールド法はデンドライト成長を精度よく再現可能な唯一 の手法として広く認められている。一方で, 個々のデンドラ イトを精度よく表現するためには十分な解像度が必要となる ため，定量モデルを用いたとしても計算コストは高く，これ まで 2 次元問題や 3 次元問題における一つのデンドライトの 再現など，その適用は限定されていた。このため, デンドラ イトスケールの表現にはフェーズフィールド法, 凝固組織を 考慮した系全体のシミュレーションにはセルオートマトン法 など，使い分けがなされてきた。現在でもこの使い分けは行 われているが, 最近の計算機の性能向上によって, フェーズ フィールド法による複数デンドライトの競合成長や液相流動 を伴う現象の再現が可能となりつつある。
本稿では，著者の最近の成果を中心に，フェーズフィール ド法によるデンドライト成長シミュレーションに関する最先 端の研究を紹介する。はじめに, 二元合金凝固のフェーズ フィールドモデルを簡単に説明する。次に, 画像処理用演算 プロセッサ（graphics processing unit: GPU）を用いたシミュ レーションについて述べる。その後, 柱状デンドライトの競 合成長, 液相流動を伴うデンドライト成長, デンドライト樹 間の透過率評価に関する研究を紹介する。いずれもGPUを 多数搭載した東京工業大学のスーパーコンピュータ（スパコ ン）TSUBAMEを用いた大規模シミュレーションによるもの である。

\section{2. フェーズフィールド法}

\section{1 モデル}

フェーズフィールド法は5 ${ }^{5)}$, ） デンドライト成長や粒成長

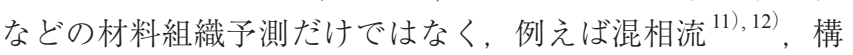
造物のトポロジー最適化 ${ }^{13)}$, 14), き裂進展 ${ }^{15)}$, 16) など, 境界 の移動を伴う問題に用いられている。最大の利点は, 界面の 位置を追跡する必要がないことである。フェーズフィールド 法では, 界面両側の状態の違いを区別するために, フェーズ フィールド変数を新しく導入し, 反応拡散方程式に帰着する フェーズフィールド方程式を数值的に解くことによって界面 の移動を表現する。

ここでは二元系合金の等温凝固を考える。フェーズフィー ルド変数を $\phi$ で表し, $\phi=+1$ を固相, $\phi=-1$ を液相と定義する。 KKS（Kim-Kim-Suzuki）モデル ${ }^{17)}$ と希薄固溶体近似を導入 すると, $\phi$ と溶質濃度 $c$ の時間発展方程式を次のように得る ことができる ${ }^{18), 19) 。 ~}$

$$
\begin{aligned}
& \tau \frac{\partial \phi}{\partial t}=W^{2} \nabla^{2} \phi-\frac{d f(\phi)}{d \phi}-\lambda \frac{d g(\phi)}{d \phi} u \\
& \frac{1}{2}[1+k-(1-k) h(\phi)] \frac{\partial u}{\partial t} \\
& \quad=\nabla D_{l} q(\phi) \nabla u+\frac{1}{2}[1+(1-k) u] \frac{\partial h(\phi)}{\partial t}
\end{aligned}
$$


なお，濃度 $c$ の代わりに無次元過飽和度 $u=\left(c_{1}-c_{1}^{e}\right) /\left(c_{1}^{\mathrm{e}}-c_{\mathrm{s}}^{\mathrm{e}}\right)$ を 用いている。 $c_{1}$ と $c_{s}$ はそれぞれ液相内と固相内の濃度, $c_{1}^{e}$ と

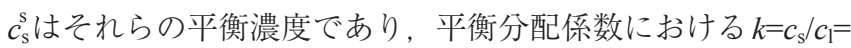
$c_{s}^{e} c_{1}^{e}$ の関係を仮定している。 $f(\phi)$ は $\phi= \pm 1$ に扔いて最小值を とる固液界面の障壁ポテンシャル, $g(\phi)$ は固液相のエネル ギーを内挿する $\phi$ の単調増加関数, $h(\phi)$ と $q(\phi)$ は, それぞ れ濃度と拡散倸数の内挿関数である。また， 緩和時間, $W$ は界面幅, $\lambda$ は熱力学的駆動力に関係する定数, $D_{1}$ は液相内の拡散係数である。

式(1) の右辺第 3 項が 0 の平衡状態の時, 第 1 項の拡散項 と第 2 項の反応項がつり合い， $\phi$ は時間変化しない。ただし， これは 1 次元問題のときだけである。拡散項はラプラシアン 演算子を含むため, 2 次元以上では曲率駆動が生じ第 3 項の 熱力学的駆動力が 0 であっても界面は移動する。第 3 項が 0 でない場合は，uの符号と絶対值の大きさに依存して界面の 移動方向と移動速度が決定される。なお，デンドライトの成 長を表現する場合は，式(1）の $\tau$ と $W$ に界面エネルギーの異 方性関数を導入する必要がある。この際，式の形は少し複雑 となる。異方性の大きさは $1 \%$ 程度と大変小さいが，この小 さい異方性を導入することで溶質拡散場の作用によって異方 性の極めて強いデンドライト形態が表現可能となる。

KKS モデルの有用性は広く認められて抢り, 式(1) と式(2) は多く用いられているが，解が界面幅 $W$ に依存する問題は 残ったままであった。な扔，KKS モデルを導入する必要性 に関しては原著論文 ${ }^{17)} も し く は$ 解説記事 ${ }^{20)}$ を参照頂きたい。 解の界面幅 $W$ 依存性の問題を解決するために, 式(2) の右 辺に $\nabla \boldsymbol{J}_{\mathrm{AT}}$ が加えられる ${ }^{18), 21)}$ 。ここで， $\boldsymbol{J}_{\mathrm{AT}}$ は antitrapping 流 束ベクトルと呼ばれ, 界面法線方向の溶質の移動量を調整 し，界面幅 $W に$ 依存しない結果を出す。このモデルを定量 的フェーズフィールド (quantitative phase-field) モデルと呼 ぶ。凝固問題では定量的モデルを用いるのが一般的となって いる。定量的モデルによって大きな界面幅，つまり大きな 数值格子を用いることが可能となり, 数值シミュレーショ ンを効率的に行えるようになった。定量的モデルはKarma $ら^{18,21)} に$ にって提案されたが, このモデルは固体内の拡散 係数を 0 としたものであった。そこで，大野らは固体内の拡 散も考慮可能な定量的モデルを構築した ${ }^{19)}$ 。さらに, 大野 らは多相系 ${ }^{22)}$, 非等温多元系 ${ }^{23)}$ への拡張を行った。定量的 モデルにおける antitrapping 項は人為的に導入されたもので あったが, Ohnoらによる変分的定式化に扔いて antitrapping 項は自然と導出されるものであることが示された $\left.{ }^{24)}, 25\right) 。 ま$ た，式(1）の界面障壁ポテンシャル $f(\phi)$ に対しては二重井 戸型ポテンシャル (double-well potential) が通常用いられて いるが, 二重障壁型ポテンシャル (double-obstacle potential) を用いても $g(\phi)$ と $h(\phi)$ を適切に選択すれば，二重井戸型 ポテンシャルを用いた場合と同程度の精度を出せることを示 している ${ }^{26)}$ 。二重障壁型ポテンシャルは, 多結晶問題にお けるマルチフェーズフィールドモデルで多用されて扔り 27), 多結晶凝固から粒成長までを統一的に高精度に再現可能なシ ミュレーションの可能性に道筋を付けた。以降のシミュレー ション例に扮いては, いずれも大野らの希薄固溶体近似を用 いた等温凝固問題に対する定量的モデル ${ }^{19)}$ を用いている。

\section{2 離散化と高性能計算}

式(1) と式(2) を見るとわかるように，空間次元を変え ても基本的に式は変わらないことがわかる。このため，2 次 元や 3 次元への展開もそう難しくはない。また, 基本的に拡 散方程式であるため, 一般的な差分法を用いて比較的容易に 離散化ができ，プログラムもシンプルである。このため，プ ログラムの並列化が行いやすいこともフェーズフィールド法 の利点である。一方で, 定量的モデルの発展によって大きな 数值格子を用いることができるようになったとはいえ, 表現 しようとする組織形態を再現しうる十分に細かい格子を用 いる必要がある。たとえば, デンドライトの 2 次元計算の場 合, 先端曲率半径の $1 / 5$ 以下の格子サイズが必要といわれて おり，これによって扔のずと計算コストは高くなる。このた め, フェーズフィールド法を用いたデンドライト成長シミュ レーションは, 2 次元もしくは3 次元に扔けるデンドライト 1 本など, 材料組織というよりもデンドライト個々を対象と したものであった。

最近, GPUを科学計算に用いる GPGPU (general purpose computing on graphics processing units）が注目され，フェーズ フィールドシミュレーションに执いても2011年頃から用いられ るようになり，現在では多くの研究で用いられている ${ }^{23,28), 29) 。 ~}$ 通常のCPUはコア数が数個から数十個であるのに対し, GPU は数千のコアを有しており, これらを並列化させることで高速 計算が可能となる。しかしながら, 条件分岐を伴うような複雑 なプログラムの並列化は得意としておらず，差分法の上うに同 様の計算を単純に繰り返すような問題に向いている。フェーズ フィールド方程式は, 先に述べたように一般的な差分法によっ て離散化が可能であり, 全格子点に扔いて同じ計算を繰り返 すだけのシンプルな計算である。加えて, デンドライト成長シ ミュレーションの場合, 式(1) に異方性関数を加える必要があ り，それらの計算に時間を要するため，格子系計算としては 1ステップに打ける計算量が多い。このため, 複数 GPUを用い た並列計算においては全計算時間に占めるデー夕転送時間の 割合が低下し, 並列計算効率は高くなる ${ }^{30)}$ 。このため, フェー ズフィールドシミュレーションはGPU 計算と大変相性がよい。 一方で, GPUは搭載しているメモリが小さいことが久点であっ た。これを補い，また計算をさらに高速化するために，著者の グループでは複数 GPU を並列化させるフェーズフィールドシ ミュレーションを行ってきた ${ }^{30,31)}$ 。現在, 単一GPUを用いた フェーズフィールドシミュレーションは多くのグループで行わ れるようになったが, 複数 GPUを並列させた計算は限られて いる。今後は複数GPU並列計算も普通に行えるようになると 予想されるが，これまでは著者のグループが独占的に行って きており，以下ではそのいくつかの結果を示す。なお，いずれ も東京工業大学の GPU スパコンTSUBAMEを用いたものであ る。TSUBAMEは数年ごとにバージョンアップしており，GPU はTSUBAME2.0では NVIDIA Tesla M2050，TSUBAME2.5では NVIDIA Tesla K20X，TSUBAME3.0 では NVIDIA Tesla P100 と 変化している。GPU P100の単精度演算性能は 9.5 TFlopsであ り, 単純な比較では現在の TSUBAME3.0は2.0 の約 10 倍高速 化している。 

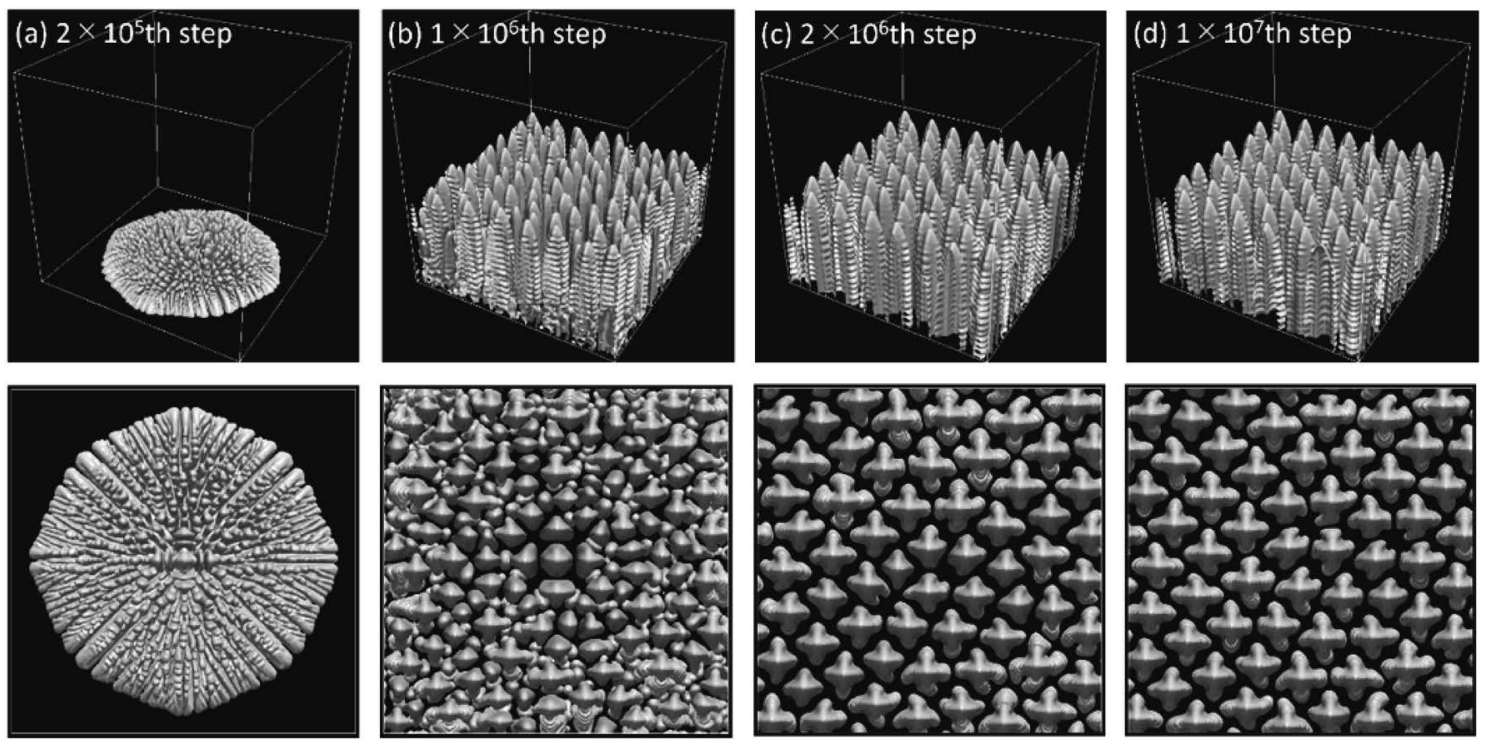

図 1 単結晶 $\mathrm{Al}-3 \mathrm{mass} \% \mathrm{Cu}$ 合金のデンドライト競合成長シミュレーション $(G=20 \mathrm{~K} / \mathrm{mm})^{41)}$ 。上図は側面図，下図 は上面図。計算領域サイズ $0.768^{3} \mathrm{~mm}^{3}$ ( $1024^{3}$ 格子点), 時間増分 $\Delta t=26.8 \mu \mathrm{s}$ 。スパコン TSUBAME2.5において 256 GPUs（NVIDIA Tesla K20X）を用いた並列計算が行われた。

\section{3. デンドライトの競合成長}

典型的な凝固組織は柱状晶と等軸晶から構成される ${ }^{2)}$ 。柱 状晶の形成過程では，鋳壁に不均一核生成した無数の固相が 熱流方向に競合しつつ成長する。この際，優先成長方向が熱 流方向に近い粒がそうでない粒を淘汰して成長し続けると いわれている。この競合成長をWalton-Chalmers (WC) モデ ル ${ }^{32 ）}$ と呼ぶことにする。フェーズフィールド法の大規模シ ミュレーションによって，一つの粒の中に複数のデンドライ 卜を含む競合成長を表現可能となり，このWC競合成長モデ ルを基に単結晶, 2 結晶, 多結晶における柱状粒の競合成長 の評価を行った。なお，いずれのシミュレーションにおいて も温度勾配 $G$ 一定の frozen temperature 近似 ${ }^{18)}$ を用い, 材料 は $\mathrm{Al}-3$ mass $\% \mathrm{Cu}$ を対象としている。

\section{1 単結晶}

単結晶材が一方向凝固する際に, 一次枝が成長方向垂直断 面内においてどのような配列になるのか興味がある ${ }^{33)} 。 一$ 次枝配列に関しては実験的評価 ${ }^{34), 35)}$ およびセル形態 ${ }^{36) ~ 40) ~}$ に関していくつか研究が行われているが, 液相流動を伴わ ない理想的な拡散状態におけるデンドライトの配列評価は 行われていない。そこで, 図1のような単結晶競合成長シ ミュレーションを行った ${ }^{41)}$ 。 $0.768^{3} \mathrm{~mm}^{3}$ の領域を $1024^{3}$ 個の 格子点で分割し, 下面中央の一つの結晶核からシミュレー ションを開始した。なお, 引抜速度 $V_{\mathrm{p}}=100 \mu \mathrm{m} / \mathrm{s}$, 時間増分 $\Delta t=26.8 \mu \mathrm{s}$ ，側面は周期境界とし，温度勾配を $G=5,10,20,50$, $100,200 \mathrm{~K} / \mathrm{mm}$ と変化させ, デンドライト形態からセル形態 までを表現した。図 1 は $G=20 \mathrm{~K} / \mathrm{mm}$ の結果を示している。計 算を開始すると，図1(a) のように下端面に沿って固相が放 射状に成長し，そこから上方向に無数のアームが成長する。 これらのアームは競合的に成長し, 図1(b) では早く成長し た中央部ではアーム間隔が比較的大きく，端部においては小 さく，全体的にランダムなデンドライト配置となっている。
しかしながら, 長く成長を続けると図 1 (c) のように初期の 影響はほとんど見られなくなり，上から見ると典型的なデン ドライトの十字形態を呈している。さらに非常に長い計算を 行うと, 図 $1(\mathrm{~d})$ のように規則的な配列が確認された。この シミュレーション結果に対して, 一次アーム先端座標を用い たボロノイ分割によって一次アームの配列を評価した結果, 図 1 (a)（b）の成長初期は四角形から八角形までの様々な配 列が確認され，無秩序な並びであった。図1(c) の状態では 一次アーム数はほぼ一定, 配列は六角形が支配的となり，ほ かは五角形と七角形が同じ数だけ存在する典型的な六角形構 造となった。なお, 図1(c) から（d）への変化では一次アー 厶数は一定であるが, 六角形構造の数は増え配列の規則度は 高くなった ${ }^{41)}$

以上のように，一方向凝固における一次アームの配列は， セルとデンドライトいずれも六角形が支配的であることを示 した。たたし，これは溶質拡散場のみの理想的な条件下にお ける定常成長状態での結果である。核生成やブランチング直 後，および実際の凝固における自然対流を伴う条件において は, 必ずしも本シミュレーション結果と同じにはならないこ とに注意いただきたい。

\subsection{2 結晶}

柱状粒の競合成長は一般的にWCモデルに従うといわれて いるが，2結晶の一方向凝固においてWCモデルに従わない

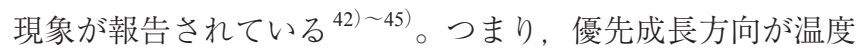
勾配方向に一致する（favorably oriented: FO）粒が, 傾いて 成長する (unfavorably oriented: UO) 粒に淘汰されるという 普通では考えられない現象である。このメカニズムを解明す るために，図2のような 2 次元 2 結晶の競合成長シミュレー

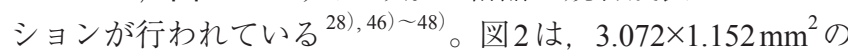
領域を4096×1536格子点に分割し, 領域の左下にFO粒の核, 右下に傾き角 $10^{\circ}$ のO 粒の核を配置してシミュレーション を開始した際の，デンドライト形態と濃度分布の時間変化で 


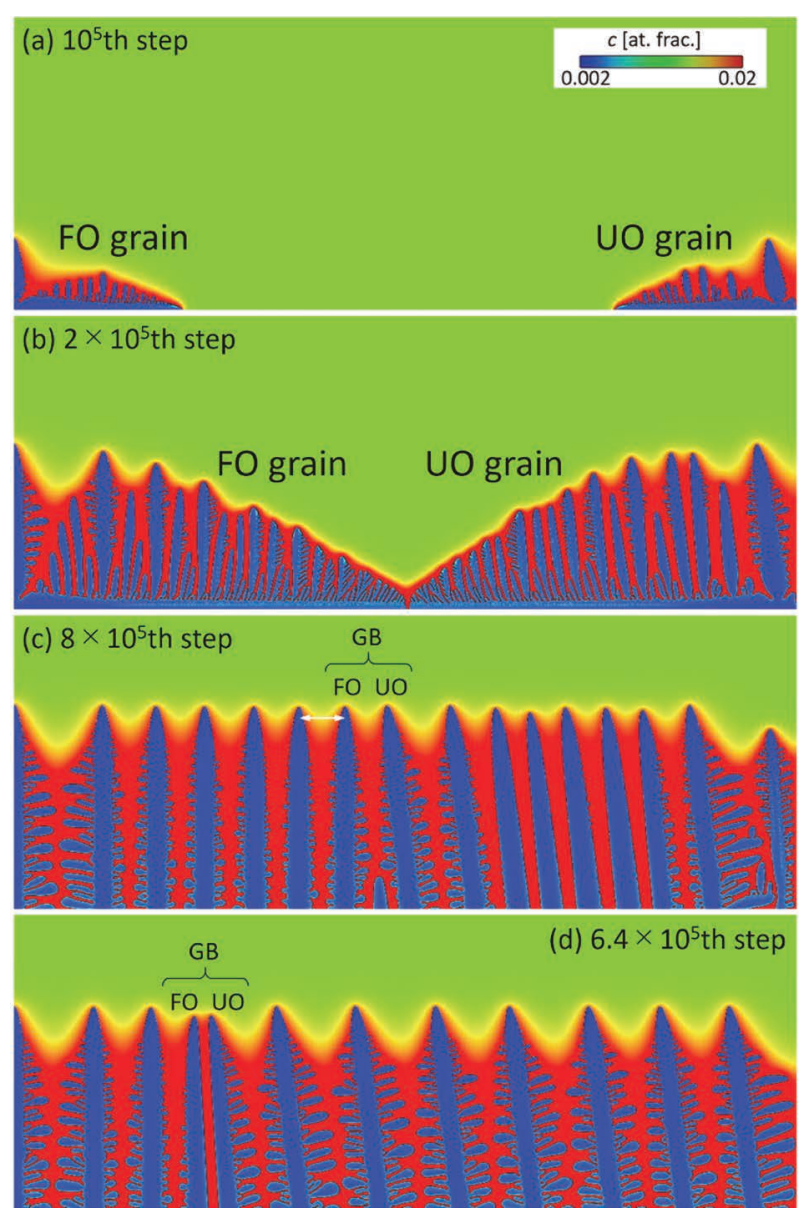

図2２次元 2 結晶 $\mathrm{Al}-3$ mass $\% \mathrm{Cu}$ 合金のデンドライト競 合成長シミュレーション $(G=10 \mathrm{~K} / \mathrm{mm})^{48)}$ 。温度 勾配方向に成長する FO（favorably oriented）粒と $10^{\circ}$ の傾きを有するUO (unfavorably oriented）粒 が，それぞれ左右に配置されている。計算領域サ イズ $3.072 \times 1.152 \mathrm{~mm}^{2}(4096 \times 1536$ 格子点 $)$, 時間 増分 $\Delta t=37.5 \mu \mathrm{S}$ 。スパコンTSUBAME2.0において 8 GPUs（NVIDIA Tesla M2050）を用いた並列計算 が行われた。

ある ${ }^{48)}$ 。引抜速度 $V_{p}=100 \mu \mathrm{m} / \mathrm{s}$, 温度勾配 $G=10 \mathrm{~K} / \mathrm{mm}$, 時間 増分 $\Delta t=37.5 \mu \mathrm{s}$, 境界はすべてゼロ Neumann 条件としている。 計算を開始すると, 図2(a)（b）のように温度の低い下端面 に沿って結晶が成長し，その後上方向に向かって多くのデン ドライトが成長している。粒内に打りる゙ンドライト間の 競合成長が終わると, 図2(c) のような定常成長になる。図 2 (c) 中の「GB」と示すところが FO粒とUO粒の粒界であり, 傾きの異なる2つのデンドライトが粒界において相互作用す る。この際, 右から移動して粒界に達したUOデンドライト は，FOデンドライトとの相互作用によって徐々にデンドラ イト先端位置を下げながら FOデンドライトに近づき, 最終 的にはFOデンドライトに淘汰される。この際, FOデンドラ イトはUOデンドライトの接近によってわずかにデンドライ 卜先端位置を下げ，わずかに左側に移動する。この相互作用 を繰り返すうちに, 図2(c) 中に白い矢印で示す FOデンド ライト間隔が，FOデンドライトが安定に成長できる臨界間 隔より小さくなると, 粒界のFOデンドライトは淘汰される。 図2(d) の粒界における FOデンドライトは, UO デンドライ 卜に淘汰される直前の状態である。粒界におけるFOデンド ライトの淘汰が繰り返されると, 眓2(d) のように徐々に粒 界が左側へ移動し，最終的にはFO粒がUO粒に淘汰される。 これがWCモデルに従わない普通でない淘汰現象とそのメカ ニズムである。

この普通でない淘汰現象は3次元問題においても観察さ れ, 同じメカニズムで淘汰が生じることが確認された ${ }^{49)} 。$ この際，2次元問題よりも3 次元問題の方が淘汰には時間が かかる。これは3 次元問題の方がデンドライト先端からの溶 質拡散領域が広くなり，粒界におけるデンドライト間の相互 作用が小さくなるためである。また，3次元においては粒界 において FO粒とUO粒の間に様々な方位関係があり，他の 方位関係に関するシミュレーションも行われている ${ }^{50)}$ 。な お，図2の計算は8個の GPU（NVIDIA Tesla M2050）を並列 させて行われたが, 最新のGPUを用いれば1つのGPUでの 計算が可能である。

\section{3 多結晶}

図2の普通でない淘汰現象は, 2 次元多結晶成長シミュレー ションにおいても多く観察された ${ }^{51)} 。$ 一方, 図3に示す3次 元多結晶シミュレーションにおいては, 図2のような現象は ほとんど観察されず，WCモデルに従った競合成長が観察さ れた ${ }^{52)}$ 。図3の結果は図 1 と同じサイズの領域を示している が，実際の計算ではこの領域の上部に 1 辺が 2 倍の格子サイ ズを用いた256格子分の領域を付加したシミュレーションを 行っている。図1の単結晶のシミュレーションとは異なり, 計算初期に64個のランダムな方位を有する固相核を下端面 に配置し計算を開始した。それ以外は単結晶の計算条件と同 じである。図3の色は，優先成長方向と温度勾配方向である $z$ 軸とのなす角度であり, 青から赤に向かって角度が小さく なる。シミュレーション初期は様々な色の粒が成長している が, 成長とともに青色の粒, 緑色の粒が淘汰され, 最終的に 角度の小さい赤色の粒が残った。このように, WCモデルに 従った結果を得た。2 次元と 3 次元における淘汰挙動の違い は, 相互作用する粒の数にある ${ }^{52)}$ 。2 次元の場合, 相互作用 は両隣の2つの粒のみであり，2つの粒界における方位関係 が普通でない競合成長を生じる条件であればその粒は長く成 長できる。一方，3次元の場合は周囲に多くの粒があり，す べての粒界で普通でない淘汰現象を生じる関係となる割合は 大変低くなる。以上のように，3 次元多結晶競合成長におい てはWCモデルに沿った淘汰現象 ${ }^{53)}$ を呈することを確認し, 2 次元問題や 2 結晶問題は特別な条件であることを示した。

\section{4. 液相流動を伴うデンドライト凝固}

地球上での合金の凝固においては必ず液相の流動が生じる ため, 液相流動を考慮した凝固組織予測シミュレーションが 必要である。フェーズフィールド法と液相流動の連成シミュ レーションにおいては, 拡散界面において滑りなし条件を満 足するBeckermannのモデル ${ }^{54)}$ が多用されている。しかしな がら, 液相流動を考慮したフェーズフィールドシミュレー ションはさらに計算コストが高くなる。このため, これま で3 次元計算 ${ }^{55), 56)}$ は限られており, 多くは2 次元問題 ${ }^{57) ~-59)}$ 
$5 \quad$ -

(a) $2 \times 10^{5}$ th step

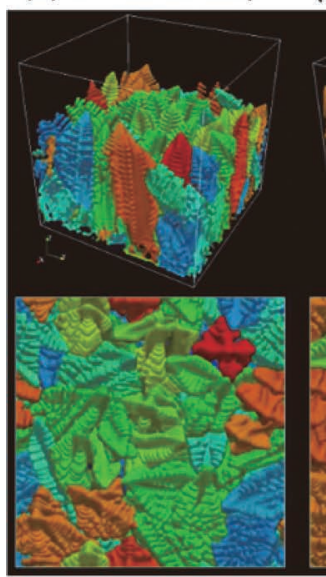

(b) $5 \times 10^{5}$ th step

(c) $1 \times 10^{6}$ th step

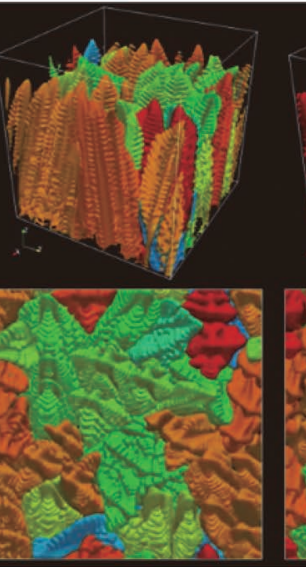

(d) $2 \times 10^{6}$ th step

(e) $5 \times 10^{6}$ th step

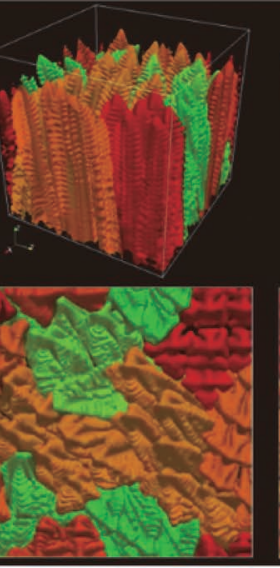

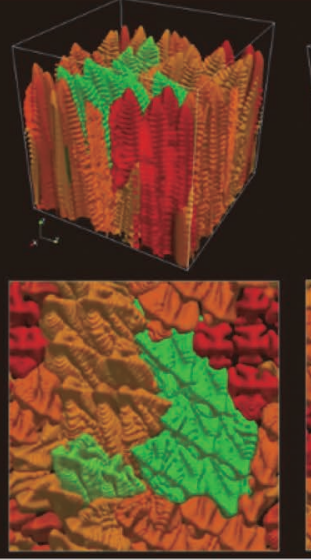

$\theta_{z}\left[^{\circ}\right] 0$

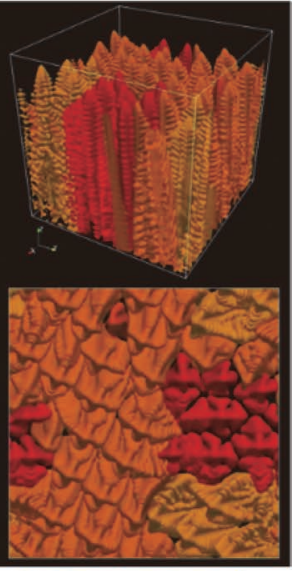

55

図3＼cjkstart多結晶 Al-3 mass\%Cu合金のデンドライト競合成長シミュレーション $(G=20 \mathrm{~K} / \mathrm{mm})^{52)}$ 。上図は側面図，下図は上面 図。シミュレーションは，下端面に置かれたランダム方位を有する64個の核から開始された。可視化領域サイズは $0.768^{3} \mathrm{~mm}^{3}$ （1024 格子点）であるが，実際の計算では上部に粗い格子を有する液相部がある。時間増分 $\Delta t=26.8 \mu \mathrm{s} 。$ スパコンTSUBAME2.5において144GPUs（NVIDIA Tesla K20X）を用いた並列計算が行われた。

(a) $1 \times 10^{5}$ th step

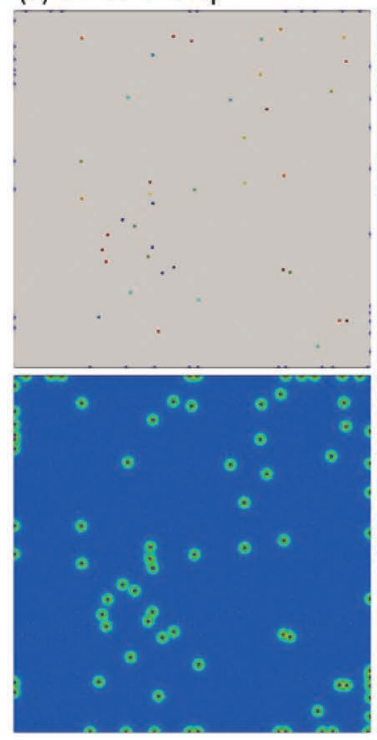

(b) $1 \times 10^{6}$ th step

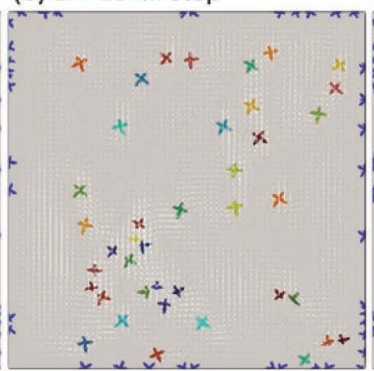

(c) $3 \times 10^{6}$ th step

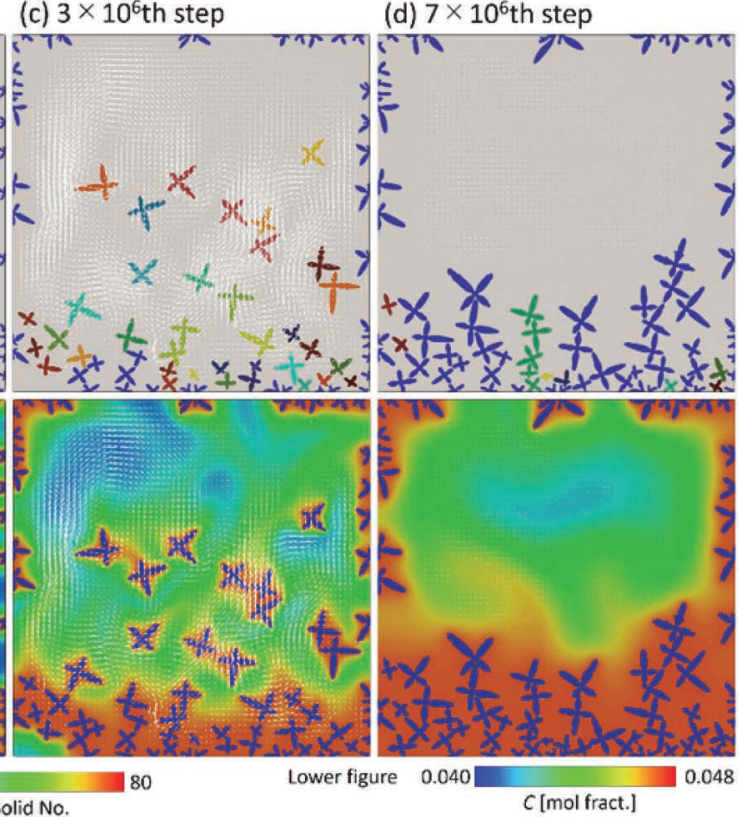

図4 サクシノニトリル-3 mass\%アセトン合金における複数の等軸デンドライトの沈降シミュレーション ${ }^{75)}$ 。上図は固 体番号, 下図は溶質濃度。領域サイズは $2.048 \times 2.048 \mathrm{~mm}^{2}(8192 \times 8192$ 格子点)。スパコン TSUBAME3.0において 16 GPUs（NVIDIA Tesla P100）を用いた並列計算が行われた。

として取り扱われてきた。この問題を解決すべく，数值シ ミュレーションの効率化に関する研究が行われている。そ れらの多くは, アダプティブメッシュ法 ${ }^{60) \sim 62)}$, 格子ボルツ マン 法 ${ }^{63)}{ }^{64)}$ ，並列計算 ${ }^{65)}$ の適用，およびそれらの組み合わ せ ${ }^{66)}$ によってなされている。

著者らは, 液相流動の計算法として並列計算の行いやす い格子ボルツマン法 ${ }^{67)}$ をフェーズフィールド法と連成させ, 複数 GPU 並列化することでシミュレーションの大規模化と 高速化を達成した ${ }^{68)}$ 。この手法を用いることで, 強制対流を 伴う3 次元デンドライト成長における収束挙動評価をはじめ て行い, 高精度な系統的シミュレーションを可能とした ${ }^{69)}$ 。
また，液相の溶質濃度に依存した密度変化による自然対流を 伴うデンドライト成長シミュレーションを行った ${ }^{70)}$ 。加え て, 液相中に孤立した等軸デンドライトの運動を伴う成長を 表現可能なモデルを構築し ${ }^{71)}$ ，GPU計算によって計算の高 速化 ${ }^{72)}$ とデンドライトの長距離移動 ${ }^{73)}$ を可能とした。さら に, このモデルを拡張することで, 複数の等軸デンドライト が運動しながら成長し, 衝突と合体を繰り返して凝固が進行 する, 等軸晶の形成過程を再現可能なモデルの構築も行っ た ${ }^{74)}$ 。また, この計算の複数GPU並列化を行うことで, 計

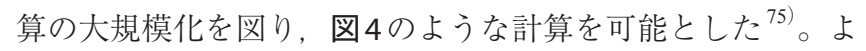
り詳細な解説は他文献 ${ }^{76)}$ を参照頂きたい。 
以上のように，液相流動を伴うデンドライト成長のフェー ズフィールドシミュレーションはここ数年でかなり発展した が, それでもまだ取り扱える領域が限られている。そのため, 計算のさらなる効率化と大規模化が必要である。

\section{5. デンドライト樹間の透過率評価}

鋳造やマクロ偏析予測のシミュレーション77) 80) におい ては, 固液共存領域つまりデンドライト樹間の液相流動のし

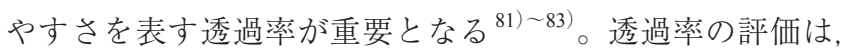
デンドライト組織予測と, その組織に液相を流して透過率を 求める2段階で行われるのが一般的である。その組み合わせ に押いて，(1)いずれも実験により評価する方法，(2)組織は実 験によって予測しそのデータを用いた流動シミュレーション による方法，(3いずれもシミュレーションにより評価する方 法の3つの組み合わせ手法がある ${ }^{84)}, 85$ )。手法(1) は流動実験 中に固相が溶けて流路が変化する問題や，内部構造がわから ないため正確な固相率や流路形状が不明な欠点がある。手法 (2)は大規模な放射光施設やシリアルセクショニング装置が必 要であり系統的な評価は困難である。このため, 手法(3のシ ミュレーションによる評価が期待されている。しかしなが ら，デンドライト形態を最も高精度に予測可能なフェーズ フィールド法は計算コストが高いため, デンドライトの一部 のみを対象とした評価しか行われて扮らず ${ }^{86)}$, 87)，透過率評 価の妥当性は不明であった。

以上のような背景を受け，大規模デンドライトシミュレー ション結果を用いる透過率評価の研究に着手した ${ }^{85)}$ 。特に 柱状組織に対する透過率評価が不十分であったため, 柱状デ ンドライト構造に対する透過率評価を行った。デンドライト 構造としては図1に示す単結晶の大規模シミュレーション結 果に対して，格子ボルッマン法を用いてデンドライトの成長 方向に垂直方向の流動を与えた。この際，圧力勾配によって 流動を与える方法を採用することで周期境界条件の適用が可 能となり, 凝固組織に対して任意の方向への流動を与えるこ とが可能となった。図 1(c) の定常成長に達した直後の組織 と, 十分に時間が経過した図1(d) の透過率はほぼ同じ結果 となった。また，図1(d) の平均一次アーム間隔を用いて, 正方形配列と正六角形配列を有するデンドライト構造に対し て透過率評価を行ったところ, 図 1(d) の結果と正六角形配 列の透過率がほぼ一致した。さらに, 固液界面の面積 $A_{\mathrm{SL}}$ と 固体の体積 $V_{S}$ の比として定義される比界面積 $S_{\mathrm{S}}=A_{\mathrm{S}} / V_{\mathrm{S}}$ を用 いた無次元透過率 $K S_{\mathrm{S}}^{2}$ は, 図 1(d) の結果, デンドライト正 六角形配列の結果， 円筒の正六角形配列に対する結果が非常 によく一致した。つまり，柱状デンドライトの垂直方向流れ に対する無次元透過率 $K S_{\mathrm{S}}^{2}$ は, 円筒の $K S_{\mathrm{S}}^{2}$ を用いればよいと いう新しい結論を得た。さらに, 多孔質材内の透過率を表現 するコゼニー・カルマンの式 ${ }^{88}$

$$
K=\frac{\left(1-f_{\mathrm{S}}\right)^{3}}{k_{\mathrm{C}} S_{\mathrm{S}}^{2} f_{\mathrm{S}}^{2}}
$$

に拀いて円筒垂直流れの係数 $k_{\mathrm{C}}$ を求めたところ， $k_{\mathrm{C}}=9$ とす ることでよい近似を得ることを確認した。等軸晶に関しては $k_{C}=3$ になるといわれており, デンドライト凝固組織の透過
率は統一的にコゼニー・カルマンの式で表現できる可能性が みえてきた。今後は, 柱状デンドライト構造の軸方向の流れ に対する評価, および透過率テンソルの評価を行う必要があ る。また, 凝固条件と比界面積 $S_{\mathrm{S}}$ の関係 ${ }^{89)}$ を求めることも 課題である。

\section{6. おわりに}

合金のデンドライト成長に対するフェーズフィールドモデ ルを簡単に説明したのちに, 著者らの大規模フェーズフィー ルドシミュレーション研究を中心に最先端のフェーズフィー ルドシミュレーションとその応用を紹介した。フェーズ フィールド法は複雑なデンドライト組織を高精度に表現可 能であり, この計算を大規模化して3次元の材料組織として の情報を得ることで, 様々な現象の解明や特性評価に用いる ことが可能となる。今回紹介した研究成果を得るためにはス パコンを必要とするが, 計算機のハード面における成長は速 く，近い将来，ここで紹介した成果はパソコン上でできるよ うになると考えられる。そうなれば, フェーズフィールド法 が組織予測法としてより身近な手法となり，その重要性はま すます増加するであろう。

\section{謝 辞}

本稿で紹介した成果は，北海道大学 大野宗一教授，東京 大学 䟠田 靖准教授, 東京工業大学 青木尊之教授, 東 京大学 下川辺隆准教授, Escuela Politécnica Nacional 准教授 Roberto Rojas 氏，京都工芸瀻維大学大学院生の坂根慎治氏と の共同研究として行われたものです。

\section{参 考 文 献}

1) J. A. Dantzig and M. Rappaz: Solidification, EFPL Press,(2009).

2) W. Kurz and D. J. Fisher: Fundamentals of Solidification, Trans Tech Publications Ltd.,(1989).

3) A. Karma and D. Tourret: Curr. Opin. Solid State Mater. Sci., 20 (2016), 25-36.

4) T. Takaki: ISIJ Int., 54 (2014), 437-444.

5) 小山敏幸, 高木知弘：フェーズフィールド法入門, 丸善出 版, (2013).

6) 高木知弘, 山中晃德：フェーズフィールド法：数值シミュレー ションによる材料組織設計, 養賢堂, (2012).

7) J. W. Cahn and J. E. Hilliard: J. Chem. Phys., 28 (1958), 258-267.

8) S. M. Allen and J. W. Cahn: Acta Metall., 20 (1972), 423-433.

9) R. Kobayashi: Physica D, 63 (1993), 410-423.

10) R. Kobayashi: Expo. Math., 3 (1994), 59-81.

11) D. M. Anderson, G. B. McFadden and A. A. Wheeler: Annu. Rev. Fluid Mech., 30 (1998), 139-165.

12) S. Aihara, T. Takaki and N. Takada: Comput. Fluids, 178 (2019), 141-151.

13) A. Takezawa, S. Nishiwaki and M. Kitamura: J. Comput. Phys., 229 (2010), 2697-2718.

14) J. Kato, S. Ogawa, T. Ichibangase and T. Takaki: Struct. Multidiscip. Optim., 57 (2018), 1937-1954.

15) C. Miehe, F. Welschinger and M. Hofacker: Int. J. Numer. Methods Eng., 83 (2010), 1273-1311.

16) K. Oshima, T. Takaki and M. Muramatsu: Int. J. Comp. Mater. Sci. Eng., 03 (2014), 1450009.

17) S. G. Kim, W. T. Kim and T. Suzuki: Phys. Rev. E, 60 (1999), 71867197.

18) B. Echebarria, R. Folch, A. Karma and M. Plapp: Phys. Rev. E, 70 (2004), 061604

19) M. Ohno and K. Matsuura: Phys. Rev. E, 79 (2009), 031603. 
20）大野宗一：Int. J. Microgravity Sci. Appl., 30 (2013)， 24-29.

21) A. Karma: Phys. Rev. Lett., 87 (2001), 115701.

22) M. Ohno and K. Matsuura: Acta Mater., 58 (2010), 5749-5758.

23) M. Ohno: Phys. Rev. E, 86 (2012), 051603.

24) M. Ohno, T. Takaki and Y. Shibuta: Phys. Rev. E, 93 (2016), 012802.

25) M. Ohno, T. Takaki and Y. Shibuta: Phys. Rev. E, 96 (2017), 033311.

26) M. Ohno, T. Takaki and Y. Shibuta: J. Comput. Phys., 335 (2017), 621-636.

27) I. Steinbach and F. Pezzolla: Physica D, 134 (1999), 385-393.

28) D. Tourret and A. Karma: Acta Mater., 82 (2015), 64-83.

29) A. Yamanaka, T. Aoki, S. Ogawa and T. Takaki: J. Cryst. Growth, 318 (2011), 40-45.

30) T. Shimokawabe, T. Aoki, T. Takaki, A. Yamanaka, A. Nukada, T. Endo, N. Maruyama and S. Matsuoka: Peta-scale phase-field simulation for dendritic solidification on the TSUBAME 2.0 supercomputer, Proceedings of 2011 SC-International Conference for High Performance Computing, Networking, Storage and Analysis, (2011), 1-11.

31) T. Takaki, T. Shimokawabe, M. Ohno, A. Yamanaka and T. Aoki: J. Cryst. Growth, 382 (2013), 21-25.

32) D. Walton and B. Chalmers: Trans. Metall. Soc. AIME, 215 (1959), $447-457$.

33) H. Jacobi and K. Schwerdtfeger: Metall. Trans. A, 7 (1976), 811-820.

34) T. Suzuki and T. Sato: J. Jpn. Inst. Met., 61 (1997), 449-455.

35) J. Hui, R. Tiwari, X. Wu, S. N. Tewari and R. Trivedi: Metall. Mater. Trans. A, 33 (2002), 3499-3510.

36) B. Billia, H. Jamgotchian and H. Nguyen Thi: Metall. Trans. A, 22 (1991), 3041-3050

37) S. N. Tewari, Y. H. Weng, G. L. Ding and R. Trivedi: Metall. Mater. Trans. A, 33 (2002), 1229-1243.

38) L. Sturz, G. Zimmermann, M. Mathes, S. Rex and B. Kauerauf: Metall. Mater. Trans. A, 35 (2004), 239-246.

39) N. Bergeon, D. Tourret, L. Chen, J. M. Debierre, R. Guérin, A. Ramirez, B. Billia, A. Karma and R. Trivedi: Phys. Rev. Lett., 110 (2013), 226102.

40) D. Tourret, J. M. Debierre, Y. Song, F. L. Mota, N. Bergeon, R. Guérin, R. Trivedi, B. Billia and A. Karma: Phys. Rev. E, 92 (2015), 042401 .

41) T. Takaki, S. Sakane, M. Ohno, Y. Shibuta, T. Shimokawabe and T. Aoki: Acta Mater., 118 (2016), 230-243.

42) N. D’Souza, M. G. Ardakani, A. Wagner, B. A. Shollock and M. McLean: J. Mater. Sci., 37 (2002), 481-487.

43) Y. Z. Zhou, A. Volek and N. R. Green: Acta Mater., 56 (2008), 26312637.

44) X. B. Meng, Q. Lu, X. L. Zhang, J. G. Li, Z. Q. Chen, Y. H. Wang, Y. Z. Zhou, T. Jin, X. F. Sun and Z. Q. Hu: Acta Mater., 60 (2012), 3965-3975.

45) H. Yu, J. Li, X. Lin, L. Wang and W. Huang: J. Cryst. Growth, 402 (2014), 210-214.

46) J. Li, Z. Wang, Y. Wang and J. Wang: Acta Mater., 60 (2012), 1478 1493.

47) T. Takaki, M. Ohno, T. Shimokawabe and T. Aoki: Acta Mater., 81 (2014), 272-283.

48) Y. Shibuta, M. Ohno and T. Takaki: JOM, 67 (2015), 1793-1804.

49) T. Takaki, S. Sakane, M. Ohno, Y. Shibuta, T. Shimokawabe and T. Aoki: ISIJ Int., 56 (2016), 1427-1435.

50) C. Guo, J. Li, Z. Wang and J. Wang: Mater. Des., 151 (2018), 141153.

51) T. Takaki, M. Ohno, Y. Shibuta, S. Sakane, T. Shimokawabe and T. Aoki: J. Cryst. Growth, 442 (2016), 14-24.

52) T. Takaki, S. Sakane, M. Ohno, Y. Shibuta, T. Aoki and C.-A. Gandin: Materialia, 1 (2018), 104-113.

53) C. A. Gandin, M. Rappaz, D. West and B. L. Adams: Metall. Mater Trans. A, 26 (1995), 1543-1551.
54) C. Beckermann, H. J. Diepers, I. Steinbach, A. Karma and X. Tong: J. Comput. Phys., 154 (1999), 468-496.

55) J. H. Jeong, N. Goldenfeld and J. A. Dantzig: Phys. Rev. E, 64 (2001), 041602 .

56) Y. Lu, C. Beckermann and J. C. Ramirez: J. Cryst. Growth, 280 (2005), 320-334.

57) X. Tong, C. Beckermann and A. Karma: Phys. Rev. E, 61 (2000), R49-R52.

58) Y. Natsume, K. Ohsasa and T. Narita: Mater. Trans., 43 (2002), 22282234.

59) J. C. Ramirez and C. Beckermann: Acta Mater., 53 (2005), 17211736.

60) R. Tönhardt and G. Amberg: J. Cryst. Growth, 213 (2000), 161-187.

61) C. W. Lan and C. J. Shih: J. Cryst. Growth, 264 (2004), 472-482.

62) C. C. Chen, Y. L. Tsai and C. W. Lan: Int. J. Heat Mass Transfer, 52 (2009), 1158-1166.

63) D. Medvedev and K. Kassner: Phys. Rev. E, 72 (2005), 056703.

64) D. Medvedev, T. Fischaleck and K. Kassner: Phys. Rev. E, 74 (2006), 031606.

65) Z. Guo, J. Mi, S. Xiong and P. S. Grant: J. Comput. Phys., 257 (2014), 278-297.

66) X. Zhang, J. Kang, Z. Guo, S. Xiong and Q. Han: Comput. Phys. Commun., 223 (2018), 18-27.

67) S. Succi: The Lattice Boltzmann Equation: For Fluid Dynamics and Beyond, Oxford University Press, United Kindom,(2001).

68) S. Sakane, T. Takaki, R. Rojas, M. Ohno, Y. Shibuta, T. Shimokawabe and T. Aoki: J. Cryst. Growth, 474 (2017), 154-159.

69) S. Sakane, T. Takaki, M. Ohno, Y. Shibuta, T. Shimokawabe and T. Aoki: J. Cryst. Growth, 483 (2018), 147-155.

70) T. Takaki, R. Rojas, S. Sakane, M. Ohno, Y. Shibuta, T. Shimokawabe and T. Aoki: J. Cryst. Growth, 474 (2017), 146-153.

71) R. Rojas, T. Takaki and M. Ohno: J. Comput. Phys., 298 (2015), $29-40$.

72) T. Takaki, R. Rojas, M. Ohno, T. Shimokawabe and T. Aoki: IOP Conf. Ser. Mater. Sci. Eng., 84(2015),012066.

73) S. Sakane, T. Takaki, M. Ohno and Y. Shibuta: Comput. Mater. Sci., 164 (2019), 39-45.

74) T. Takaki, R. Sato, R. Rojas, M. Ohno and Y. Shibuta: Comput. Mater. Sci., 147 (2018), 124-131.

75) Y. Shibuta, M. Ohno and T. Takaki: Adv. Theory Simul., 1 (2018), 1800065.

76) 高木知弘：混相流, 32 (2018), 337-344.

77) M. Ohno and H. Sato: Int. J. Heat Mass Transfer, 127 (2018), 561-570.

78) M. Ohno and H. Sato: ISIJ Int., 58 (2018), 114-122.

79) T.-T.-M. Nguyen, C.-A. Gandin, H. Combeau, M. Založnik and M. Bellet: Metall. Mater. Trans. A, 49 (2018), 1725-1748.

80) 及川勝成, 平田直哉, 安斎浩一：鉄と鋼，103（2017），747754.

81）大中逸雄：まてりあ, 53（2014），462-466.

82) C. Beckermann: Int. Mater. Rev., 47 (2002), 243-262.

83) M. C. Flemings: ISIJ Int., 40 (2000), 833-841.

84) 霖 千修, 高橋大喜, 河嶋佳純, 谷川英司, 大笹憲一：鉄と鋼, 99 (2013), 117-125.

85) T. Takaki, S. Sakane, M. Ohno, Y. Shibuta and T. Aoki: Acta Mater., 164 (2019), 237-249.

86) B. Böttger, C. Haberstroh and N. Giesselmann: JOM, 68 (2016), $27-36$.

87) A. Ludwig, A. Kharicha, C. Hölzl, J. Domitner, M. Wu and T. Pusztai: Eng. Anal. Bound. Elem., 45 (2014), 29-35.

88) P. C. Carman: Flow of gases through porous media, Academic Press, New York,(1956).

89) H. Neumann-Heyme, K. Eckert and C. Beckermann: Acta Mater., 140 (2017), 87-96. 